\title{
Head-Hunting Among the Hill Tribes of Assam
}

\section{T. C. Hodson}

To cite this article: T. C. Hodson (1909) Head-Hunting Among the Hill Tribes of Assam, Folklore, 20:2, 131-143, DOI: 10.1080/0015587X.1909.9719869

To link to this article: http://dx.doi.org/10.1080/0015587X.1909.9719869

$$
\text { 曲 Published online: } 14 \text { Feb } 2012 .
$$

6 Submit your article to this journal 4

Џll Article views: 1

Q View related articles $\longleftarrow$ 


\section{HEAD-HUNTING AMONG THE HILL TRIBES OF ASSAM.}

BY T. C. HODSON, RAST LONDON COLLEGE.

\section{(Read at Meeting, February 17th, 1909.)}

My knowledge of head-hunting as an incident of life on the frontier of Assam dates from a visit,-in an official capacity, with an appropriate escort of military police,to a village in the remotest corner of the State of Manipur. My friends, as they afterwards became, did not oppose, but did nothing to facilitate, my entry, and even thought it necessary to pay us the compliment of distributing panjis, or sharpened bamboo stakes, in the pathways leading to the village. By careful strategy, and neglect of the usual methods of frontal attack, we got inside unscathed, and at once proceeded to diplomatic negotiations. Two heads had been taken, and with us was the uncle of one of the gentlemen who had come to his end in the row. The first interesting fact I learnt was that, in this village, it was customary not to keep the heads of enemies inside the village, but to place them in a tree outside. Here I may observe that, among the naked tribes of Tamlu, in the hills north of Kohima, the headquarters of the Nãga Hills District, and among the Kukis ${ }^{2}$ south of Manipur, and again south among the

I Assam Census Report, 1891, vol. i., p. 246.

- M'Culloch, Accoumt of Munnipore etc., p. 63. 
PIATE IV.

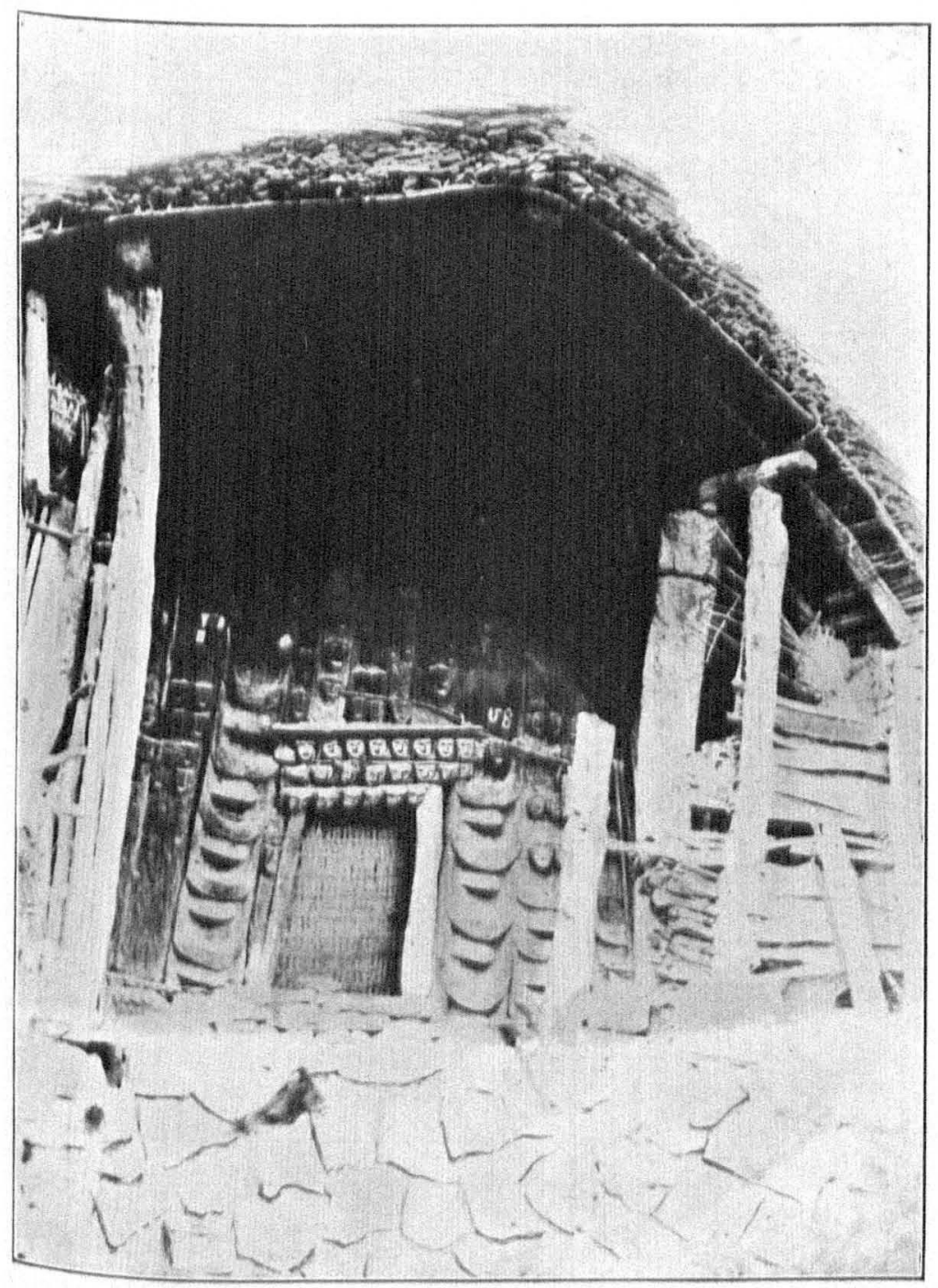

Näga House, Showing Head Decoration. 


\section{Head-Hunting among Hill Tribes of Assam. I33}

Lushei tribes, ${ }^{8}$ traces of tree burial are found, so that the practice of placing the head of an enemy in a tree may be remotely connected as a ceremonial survival with a practice, once general, which has now become obsolete." It was no easy matter to persuade the Nāgas of my frontier that the heads had to be restored to the friends of those to whom they had belonged, but arguments and stubborn facts prevailed in time to prevent the necessity of recourse to other methods of persuasion.

This incident was only a case of self-defence in a sudden quarrel, and was amply punished by six months' hard labour,-not, let me observe, for murder, but for the offence,-which is not yet formally in the statute book,of cutting off the head of a fallen foe. Another incident which happened to me in the neighbourhood, but months later, brought me into contact with yet another phase of head-hunting. I myself was busy with the census, an operation which in the Meithei language is described as head-seeking, ( $m i \bar{k} k k$ thi-ba, to seek the heads of men). I was marching ahead of my commissariat, when suddenly at my feet fell a pitiable creature, a Năga in as abject a state of terror as poor humanity could be. It took me some time to get a clear understanding of his distress. The headman of a large and powerful village over the border and outside my jurisdiction was engaged in building himself a new house, ${ }^{b}$ and, to strengthen it, had seized this man and forcibly cut off a lock of his hair, which had been buried underneath the main post of the house. In olden days the head would have been put there, but by a refinement of some native theologian a lock of hair was held as good as the whole head, for the ghost of the wretch would go there and seek the missing lock and be

'Capt. T. II. Lewin, Hill Tracts of Chittagong atc., p. 112.

'See Grant Allen, The Attis of Caiws Valeriws Calullus, passim.

"Cf, L'Annde sociologique, vol. il., p. ro4; Grant Allen, op. cit., pp. I17 it seq. 


\section{34 Head-Hunting among Hill Tribes of Assam.}

for ever compelled to remain beneath the post. This is the motif of the earthquake story of the Kabui Nagas ${ }^{\circ}$ in Manipur, who declare that once upon a time a father-inlaw and a son-in-law quarrelled and fought, and the lady, seeing her husband and father locked in mortal combat, rushed on them and pulled them apart, and in so doing tore a lock of hair from her husband's head, which she threw into the fire. So the struggle still goes on, and they fight over the lost lock till parted once again. When I visited the headman who had done this evil thing to my unhappy Nãga, I had it in me to persuade him that the ghost of a stout buffalo would prop up his house as well as, possibly much better than, the thin wailing ghost of a half-starved Manipur Näga. I succeeded in inducing him to avail himself of the law of substitution. Glimpse number two into the ethics of head-hunting was not long after followed by a rare and delicate compliment which was paid to me by the headman of an interesting village who, as a great and special favour, showed me the famous war-stone on which no woman may look and live, and to which, after a raid, the heads of the victims were shown in the bad old days, which are perhaps gone for ever, or till the next time.

In Tangkhul villages are heaps of stones,-places of great sanctity-lai-pham as the Manipuris call them,the abodes of a lai, a powerful mysterious entity,- not always nor necessarily anthropomorphised. On these

- See Plate V., in which notice may be taken of the leggings worn by the right-hand figure. In most cases white earth is smeared over the legs on ceremonial occasions, but is now sometimes replaced hy white cotton leggings. The dao carried by the left-hand figure is of a peculiar pattern, quite unlike that in ordinary use.

The photograph of a Mao Naga chief, Plate VI, shows the strange attire affected by a warrior in full dress. IIe wears a headdress which bears some resemblance to horns, and a tail as an additional decoration. Are these distant reminiscences of "totemistic" belief? Ile has doll in his left hand, which suggeats a "head." 
PLATE V.

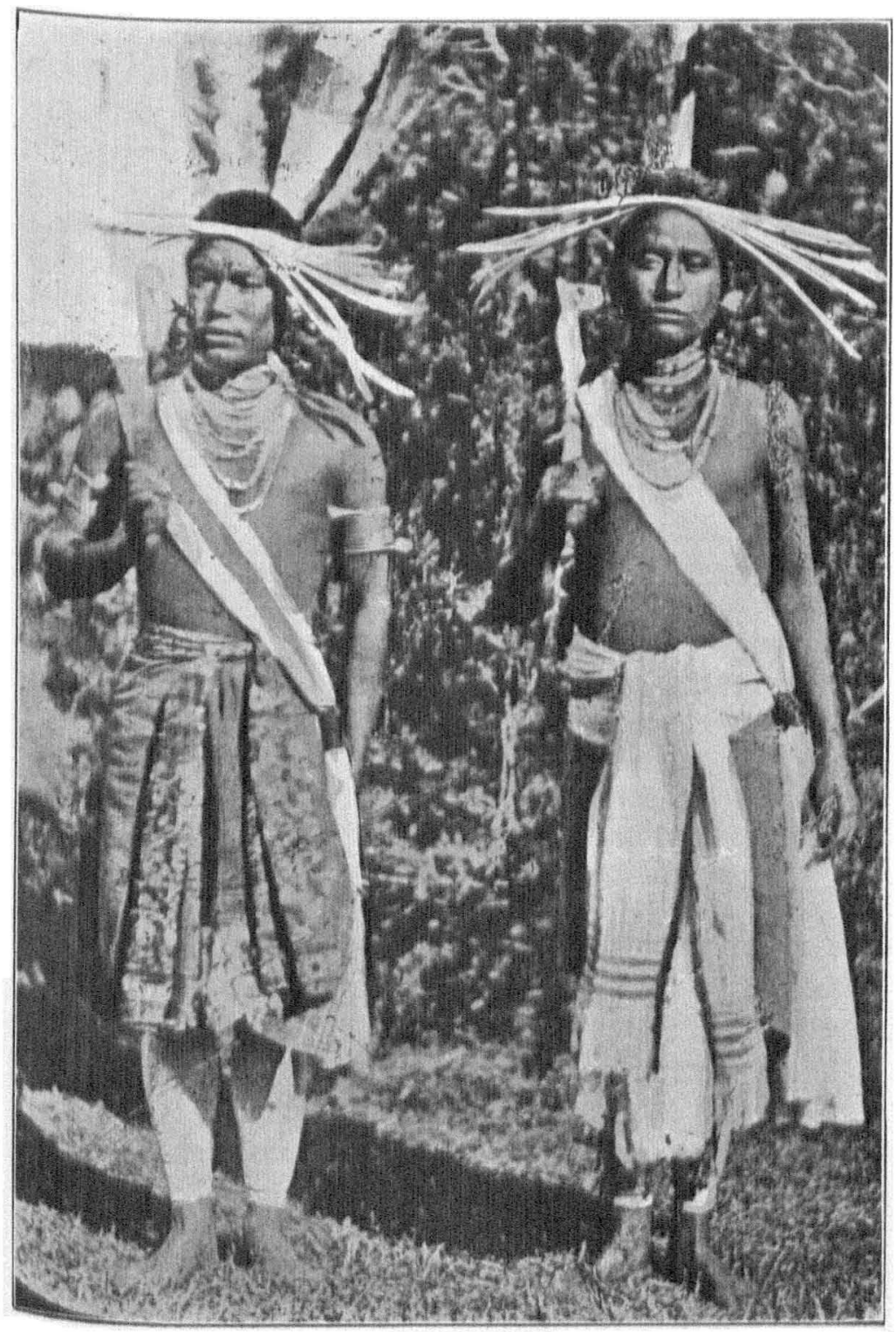

Kabui Nāgas. 
heaps the heads taken in a raid were placed for five days, during which the warriors were genna,-subjected to a process of tabu which had, I fancy, for its object the "desacralisation" of the warriors, since before they go on a raid they are similarly tabu. I may note that an oath taken on these stones is regarded as most binding.

I find other associations of head-hunting with stones in this area which may help us. In the Ning-thau-rol, or Chronicles of the Royal House of Manipur, I find a passage declaring that at an early date a king of Manipur brought a holy stone from a Nãga village, placed it in the Palace, built a wall around it, and appointed that place for the burial of the heads of the victims killed in war. Without straying too far into an alluring digression on stone monuments in the area I deal with, I may point out that stone monuments are often erected inter vivos in order to secure stability and good fortune for the family, as is said to have been the intention of those who erected the remarkable group of stones at Willong, shown in Plate VII. ${ }^{8}$ Stones are noticed in the Manipur Chronicles as exercising influence over the food supply of the people. In 1854 there was a scarcity of fish, which was attributed to the removal of a stone from its site in the Bazaar to the Temple of Nung säba, literally "the stonemaker," one of the pre-Hindu deities who survived the reforms of King Pamheiba. The Chronicles of Manipur, I may observe, are of much interest because they tell against the extravagant pretensions of a section of the Meithei community, and because they frankly describe the various recensions to which they have been submitted. As historical documents their value has yet to be proved. As ethnological material, they are distinctly worthy of note for the glimpses of native life and thought which they offer to

\footnotetext{
"Plate VII. is from a photograph by Lieut..Col. L. W. Shakespear, late Commandant of the Naga Irills Military Police.
} 


\section{36 Head-Hunting among Hill Tribes of Assam.}

us even in their most inflated descriptions of the splendour that is now departed.

Among the acquaintances which I made during my census tour was an elderly rather decrepit Kuki, with an unquenchable thirst, and a memory. My interest in him awoke when I saw his feats with the flagons of beer, but it was more than maintained when he opened to me the stores of his recollections. He had taken part in more than one notorious raid, and chuckled with glee over the discomfiture of the expeditionary columns which had wearily tramped the hills, burnt some villages,-in more than one case quite innocent villages, (at any rate so far as the immediate outrage was concerned),-and had marched home like the King of France and his forty thousand men. In all these raids on tea gardens one and only one motive was at work, the desire to secure heads to grace the funeral of some chief. My garrulous friend was not clear as to the reason why the heads were needed, or what useful purpose they served, except that their owners became the slaves of the chief in the future world. I found this belief among my Näga tribes, and with it the view that one of the many compartments into which heaven is divided is reserved for those whose heads have been cut off.

Clearly the precise significance of head-hunting as ancillary to and as part of funeral rites can only be ascertained by consideration of funeral ritual as a whole, and of the causes which determine it. It is characteristic of funerary ritual in this area that through eschatological belief it is affected by considerations, (I) of the social status of the deceased, and (2) of the manner of his death. In life the Kuki chief is conspicuously the secular head of his village. His funeral is incomplete without the head of a human victim. His body is placed inside the trunk of a tree, - - surely again a survival of note,--there

- Transactions of the Third International Congress for the Mistory of A'oligions, vol. L., p. 58 ; M'Culloch, loc. cit. supra. 
PIATE VI.

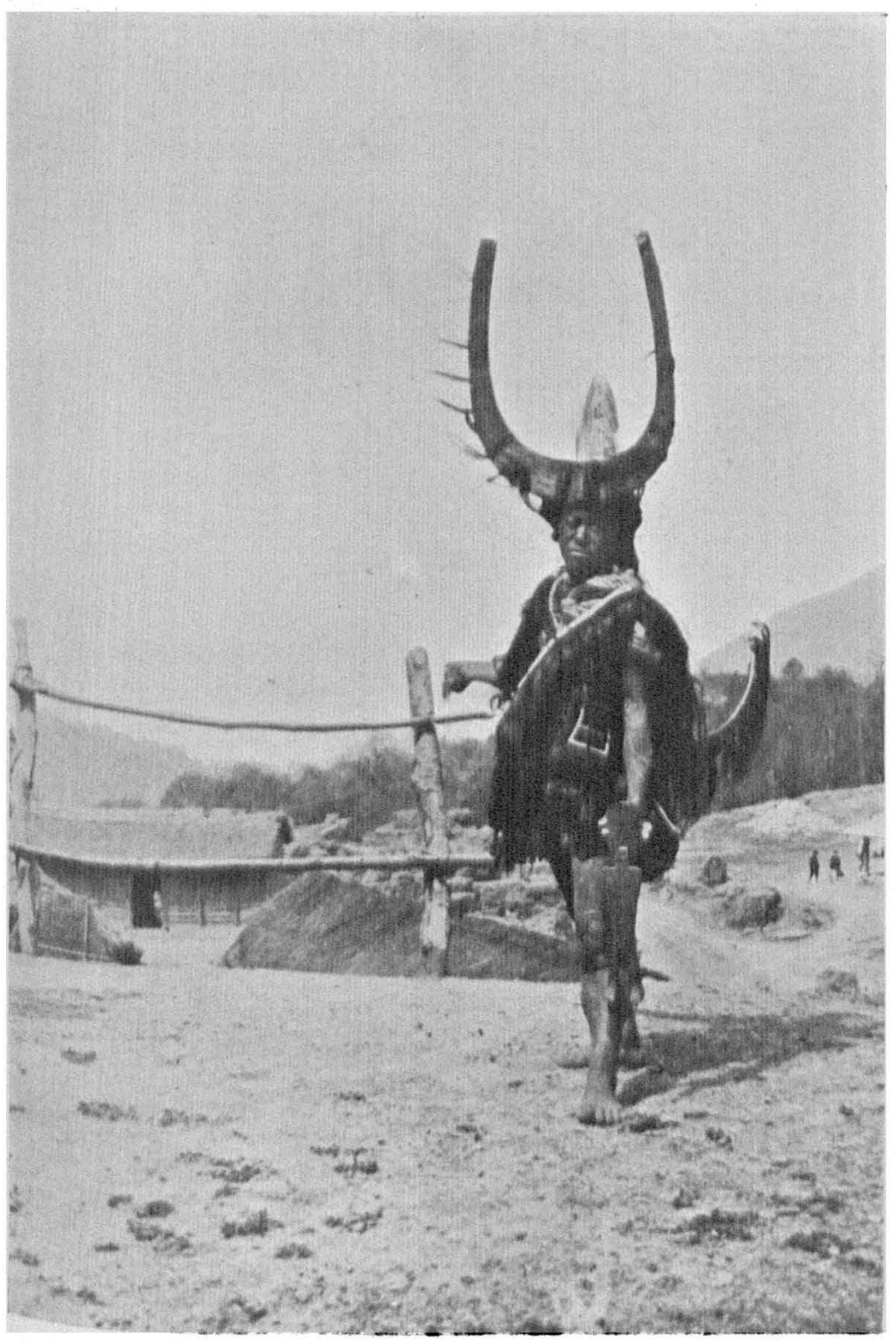

Mao Nãga Chief. 
subjected to a desiccatory process, and his bones kept. In all funeral rites in this area I see a double motive at work, affection and respect for the dead as well as fear, not only of mortal contagiosity, but also of malignant ghostly activity. Head-hunting may serve a double purpose. It may be piacular and propitiatory, intended both to placate the powerful ghost and to prevent danger. In another aspect I venture to compare it with the interesting rites to which the Lusheis give the name ai, a term which, as a noun, is defined by the authors of the Lushei dictionary ${ }^{10}$ as meaning " the power of fascinating, charming, or getting power over," and, as a verb, as meaning "to perform a ceremony in order to get the spirit of a wild animal killed in the chase into one's power after death." An $a i$ ceremony is performed by a living person for his own benefit after death. A domesticated animal is killed, and by the sacrifice and by a rite which is described by my friend, Colonel Shakespear, C.I.E., D.S.O., in a paper before the Anthropological Institute not yet published, the successful hunter gets power over the spirit of the animals he has killed. Is the human victim, - a stranger always, a slave sometimes, - a Bengali sometimes, - -killed by the community as a solemn communal act in order that it may get some power over, remain in possession, as it were, of, the great man who has been reft from them? In life he was a great one of this earth. It would, therefore, be to their advantage as a community to keep in touch with such an one. This is at least in part the motive for preserving the bones of the chief with jealous care.

I must confess that $\mathbb{I}$ have often regretted my ignorance of ethnology when making my enquiries in this interesting area, but among the interrogatories in my questionnaire was one relating to head-hunting, and I can even now

\footnotetext{
${ }^{10} \mathrm{~J}$. II. Lorrain and F. N. Savidge, A Grammar and Dictionary of the Lustai Langwage (Dulion dialoct), p. 54.
} 


\section{I38 Head-Hunting among Hill Tribes of Assam.}

recollect the thrill of pleasure that went through me when in reply to my questions the Quoireng Nāgas, now quite a small tribe conterminous with the $K_{\text {abuis }}$ on the northwest corner of the Manipur State, told me that they used to take heads because the possession of a head brought wealth and prosperity to the village. They added that it was usual to keep the gruesome trophy for five days, and then to return it to the village to which it belonged. Sometimes it was put in the grave of the family of the successful warrior. Then for three years all raids on the particular village were forbidden. Both they and their neighbours practise a custom which $I$ am disposed to connect with the practice of head-hunting. They erect outside the village an image of a man, made either of straw or of the stem of a plantain tree, and throw spears at it. If a spear hits the head, the successful marksman will take a head, while, if he hits the belly of the image, the crops will be good. As Colonel M'Culloch remarks in his valuable, but alas! little-known, Account of Munnipore and its Hill Tribes, (page 52), "this festival is said to be in honour of their ancestors, but the only visible sign of this is sprinkling the graves with their particular drink." Then they take the omens for their future cultivation as "a ceremonial relic of former times." I have elsewhere ${ }^{11}$ described the ceremony of taking the omens for the cultivation, and will only say here that it is of much interest. There are one or two points which deserve notice in this custom. The first is that the three years' truce seems to be connected with the fact that the tribes find that even good soil is exhausted by two years of jhum cultivation with fire and axe. They thus change their fields every third year. ${ }^{12}$ The next point is that we have in the shooting rite a survival of human sacrifice, so that we may fairly consider ourselves face to face with a

12 The Journal of the Antkropological Instituse oft., vol. xxxvi., p. 95.

12 Assam Census Seport, vol. i., p. 243. 


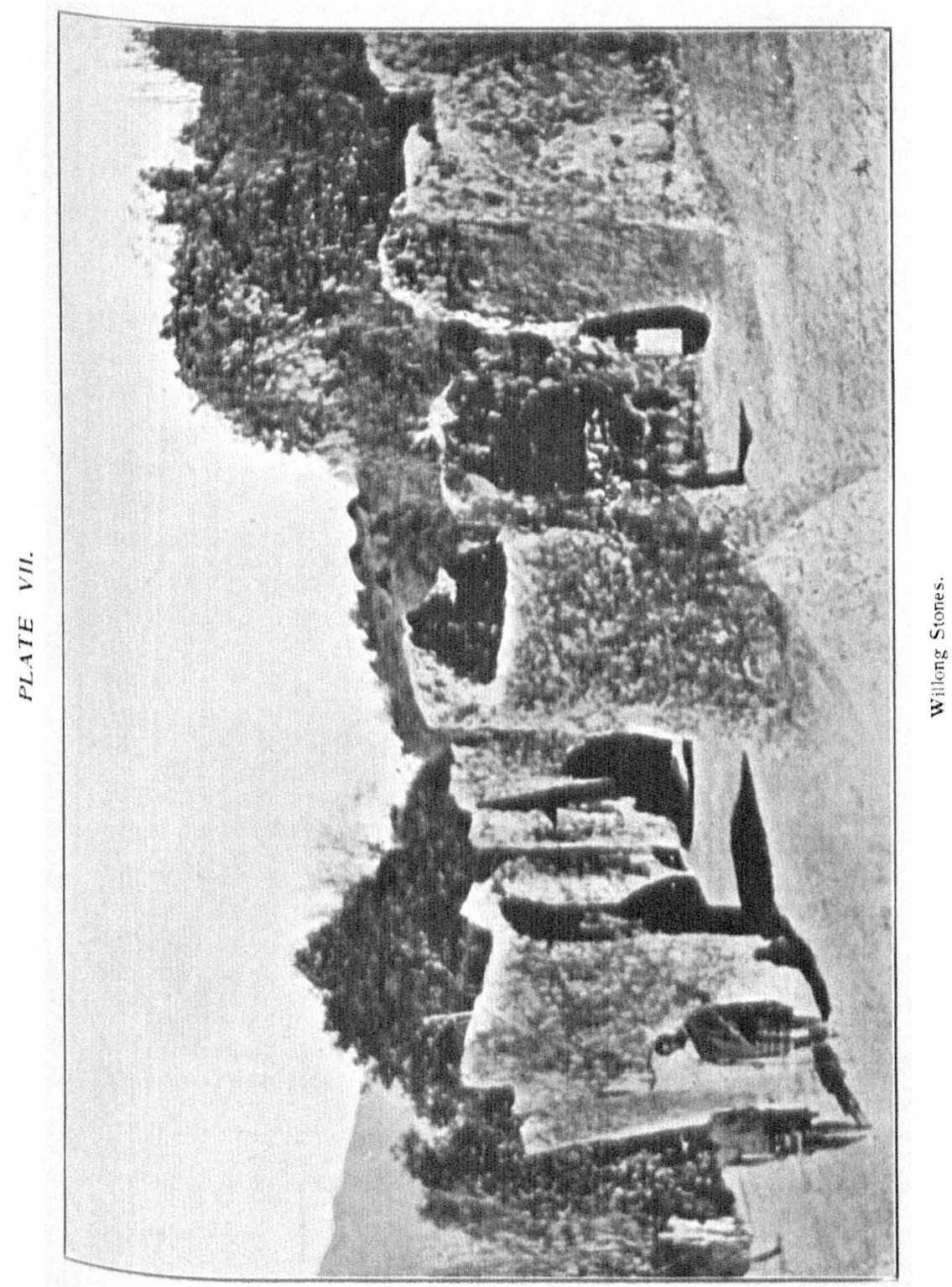


"trieteric" 18 agricultural rite, which has now become annual and which had for its purposes, firstly, the fertilisation of the new area to be brought into cultivation, and, secondly, some more remote benefit to the living and the dead, especially the recently dead. It has often seemed to me, when attempting by the light of nature to work out the comparative chronology of the village festivals in this area, that I ought to remember that,-(I) these tribes mark off the year into a cultivating and a hunting period with some sharpness, (2) that the festivals therefore which mark the conclusion of the cultivating season may also serve to mark the opening of the hunting season, (3) that the annual festival in honour of the dead that have died within the year also takes place,- when and where held,at the end of the cultivating season, and (4) that it is quite possible that what were originally distinct and separate festivals, (a) for the end of the agricultural season, or $(b)$ for the beginning of the hunting season, and $(c)$ for the benefit of the recently dead, may now have been merged into two, or into even one festival. If hunting was ever, at any stage of their tribal history, the mainstay of life, it is intelligible that the commencement of the hunting season should be marked by a rite in honour of the mighty dead whose hunting prowess was still remembered.14 The Kukis still consult the bones of their dead chiefs, ${ }^{15}$ and the skulls and horns of the trophies of the chase form not the least important of the decorations of the graves of the dead.

To return to head-hunting, it is worthy of note that, in the gentle art of oneiromancy as practised by the Nägas of these hills, the accepted interpretation of dreaming that

\footnotetext{
${ }^{13}$ Farnell, Transactions of the Third International Congress for the History of Religions, vol. Ii., p. 140.

"Seligmann, "The Vedda Cult of the Dead," Transactions of the Third International Congress for the History of Religions, vol i., pp. 59 et seq.

${ }^{16}$ Lewin, loc. cit. supra.
} 


\section{Head-Hunting among Hill Tribes of Assam.}

one has taken an enemy's head is that good health will be the portion of the dreamer, or that he will enjoy good hunting. I have found that actually to do the thing and to dream of doing it have in popular belief the same meaning, and, just as to dream of being attacked by a buffalo means that one will lose all one's cases in the Courts, (for the law's uncertainties are as certainly uncertain in Manipur as in any other part of the King's dominions), and as any Näga who has a case on would compromise it at any price if in the flesh he were attacked by a buffalo, so I venture to infer that the actual capture of a head may be regarded as bringing health and good hunting. But there are other ways of securing for the community at large these desirable advantages, village rites which are marked by strict food tabus, by the separation of the sexes, and by a sacrificial feast. In one village the young men go out together and try to shoot a hornbill, of which the feathers form a much prized decoration, and, if they succeed in bringing home a fine large bird, the village will be secure from all illness in the coming year. In other villages there is a village genna or imposition of special social tabus with a communal feast which has for its object the prosperity of the hunting season. So, too, for the welfare of the rice are there village gennas, while clan and household gennas are held on all the critical times of life..$^{16}$

Earlier authorities declare that no young man could find a wife for himself until he had taken $a$ head and thereby won the right of the warriors' kilt, shown in Plate VIII., or of the necklace of bears' tusks and the wristlets of cowries. Nowadays these are worn as ornaments without much, if any, thought of the fact that not very long ago they were regarded as affording magical protection and as bringing strength. In $189 \mathrm{I}$

16 "The "Genna" amongst the Tribes of Aasam," The Journal of the Anthropological Institute etc., vol. xxxvi., pp. 92 at seq. 
PLATE VIII.

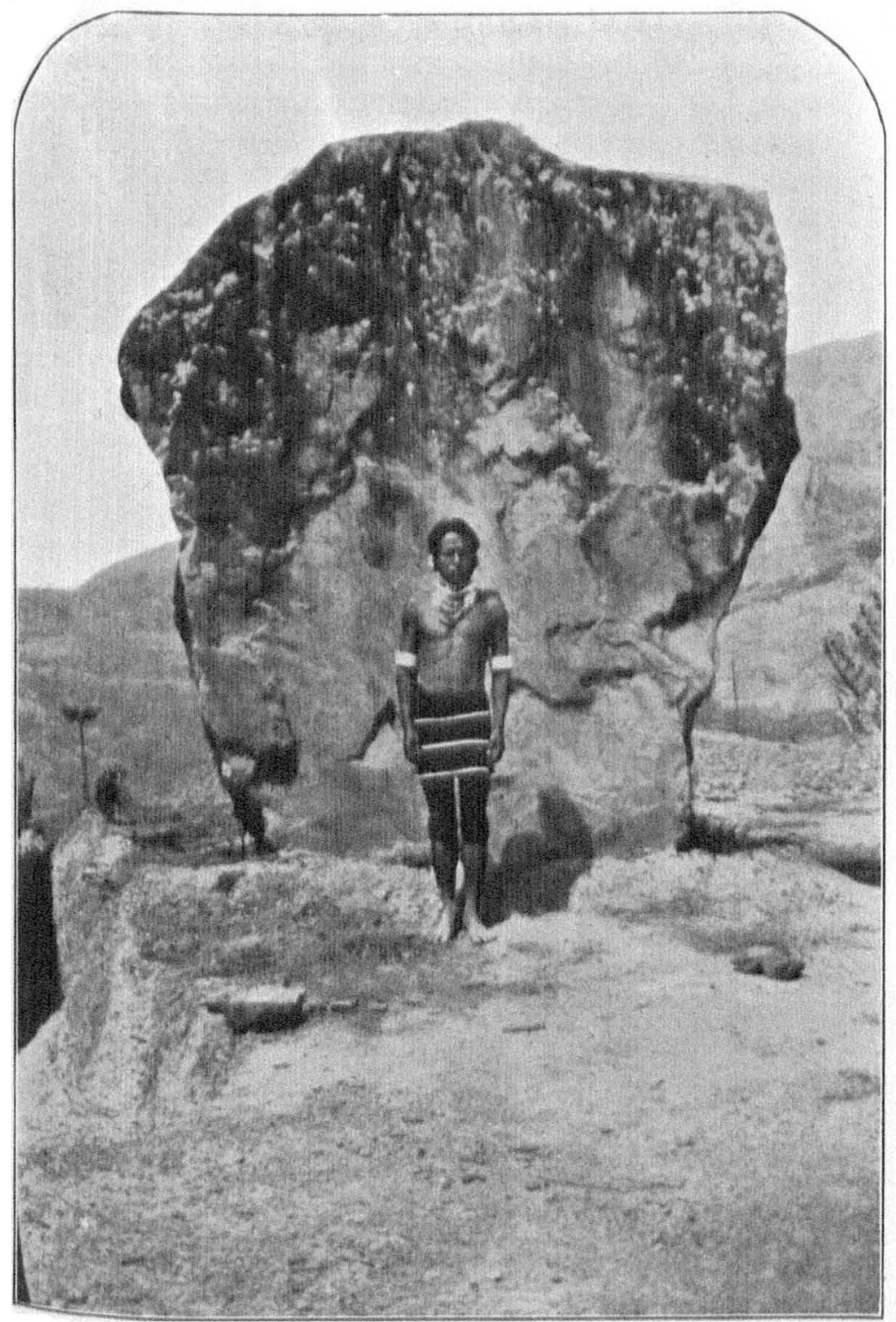

Maräm Näga. 
Davis noted the beginnings of the degradation of this custom, and observed that the desire for head-hunting was more the fault of the women than of the men, who were laughed at if they turned out at the village festivals without the decorations assigned to the successful warrior. ${ }^{17}$ I am myself inclined to believe that success in headhunting was at one time, if not essential to marriage, regarded at least as a token of having passed from adolescence to maturity. At Maram I heard a folk-tale which is narrated by M'Culloch, ${ }^{18}$ and which portrays the chief sending forth his sons, who claimed the inheritance, to take a head, and awarding the prize to the beloved but unwarlike elder son who had a head ready in a safe place, while the younger son, the bolder man, went far to win the trophy. The tale was doubtless invented primarily to explain the dual chiefship of this village, but, when we find among the Tangkhuls a custom which makes the marriage of the son the occasion for bringing into play the laws of inheritance and for necessitating the retirement of the village chief in favour of his son, a young vigorous man in the plenitude of health and strength,--thus securing for an important office a continuity of vigorous service to which the utmost value is attached,-we may agree that success on a head-hunting raid would fairly serve as a mark of manhood and as qualifying for promotion from one stage in tribal life to the higher stage of married man. Examination of the details of the village rites and structure shows quite clearly that we have, first, the necessary stage where the children are too young to leave maternal care and where they remain at home, then the stage where they leave home at night and sleep, and on high days and holidays eat, apart from their parents in separate houses, and then the matrimonial stage where they begin their married life with severe prohibitions

"Assam Census Refort, t89t, vol. i., p. 249.

is $O p$. cit., p. 69. 


\section{Head-Hunting among Hill Tribes of Assam.}

against marital intercourse inside the house for a period varying in length from three to twelve days,-and where, in some tribes, they do not pass the night together at any time, since the men are required still to sleep in the bachelors' house, while the women and children sleep in separate family houses. The last stage of all marks, as it were, the retirement of the warrior from active life, and he is now permitted to live with the women and to leave the bachelors' house for good. The evidence for this grouping rests, in part on the allocation of ceremonial duties among these groups, in part on the actual narratives of the people themselves, and in part on the fact that greater responsibility attaches to the married than to the unmarried, - not that marriage is held by them to ber what it undoubtedly is, a liberal education in itself, but that it marks adult manhood from youth, completes the process by which the clan maintains itself, and is a title to full rights and duties.

A raid in order to get a head is a religious business, and not lightly undertaken, whatever its motive. They may think killing "fine sport," 10 but they prepare themselves for the sport with solemn rites. Before, as well as after, a raid the young warriors are genna, secluded from intercourse or speech with women, compelled to live apart. It is strange to see how slight on the whole has been the mitigation of intertribal feud wrought by the law of exogamy, which is as fundamental in social belief as the duty of blood revenge. Here and there the women of especially warlike and powerful villages are eagerly sought in marriage, because their relations will avenge them if aught happens to them, ${ }^{20}$ but the feuds would still persist but for the gentle restraints of British administration. Marriage is entirely a peaceful arrangement, and war songs are forbidden at the wedding ceremonies, presum-

10 Assam Census Report, t89i, vol, i., p. $23^{8}$.

${ }^{20} \mathrm{Cf} . \mathrm{M}$ 'Culloch, op. cit., p. 68. 
ably because they are incongruous at a transaction of so different a nature.

I do not think it possible to reduce head-hunting to a single formula. I have found it connected with simple blood feud, with agrarian rites, and with funerary rites and eschatological belief. It may again be in some cases no more than a social duty,--obligatory upon those who seek to prove their fitness for initiation into tribal rites. It is compatible and co-existent with a strong sense of 8ocial solidarity, and it may be argued to be a survival,stripped of much of its original significance, since it is observed among people who from the aspect of material culture are not primitive in that sense of that much-abused term, who are skilled in the arts of agriculture, weaving, and metal-work. But a society may be, in respect of its material culture, comparatively advanced, and yet exhibit a relatively low level of mentality.

Outside, but adjacent to, the area with which I am personally acquainted and from which I have drawn my facts, there are many tribes, speaking languages which are related to the Tibeto-Burman stock, with which the Nàgas and Kukis have many striking affinities, among Whom head-hunting still flourishes. The wild $\mathrm{Wa}$, for instance, have introduced strictly business methods and have a definite tariff for heads."2 Apparently there is no market in European heads as yet. Would it be out of place or unseemly to hint that the Wa country offers an admirable field for experiments in the direction of Tariff Reform ? ${ }^{22}$

\section{T. C. HODSON.}

\footnotetext{
"Risley, Ethnography of India, quoting Sir George Scott, pp. 214 at Ste.; Upper Burma Gasetteer, vol. i., part I., pp. 496 et sey.

${ }^{2}$ Plate IV., prefixed to this paper is from a photograph hy Lieut.-Cal. J. Shakespear, C.I.E., D.S.O., Political Agent in Manipur.
} 